\begin{tabular}{|c|l|}
\hline Title & Localization and subcellular distribution of prolyl oligopeptidase in the mouse placenta. \\
\hline Author(s) & Matsubara, Shin; Takahashi, Takay uki; Kimura, A tsushi P \\
\hline Citation & $\begin{array}{l}\text { Journal of molecular histology, 42(3), 251-264 } \\
\text { https://doi.org/40.1007/S10735-011-9329-3 }\end{array}$ \\
\hline Issue Date & 2011-06 \\
\hline Doc URL & http://hdl.handle.net/2115/46898 \\
\hline Type & article (author version) \\
\hline File Information & Matsubara JMH-2.pdf \\
\hline
\end{tabular}

Instructions for use 


\section{Localization and subcellular distribution of prolyl oligopeptidase in the mouse placenta.}

2

3 Shin Matsubara ${ }^{\mathrm{a}}$, Takayuki Takahashi ${ }^{\mathrm{a}, \mathrm{b}}$, and Atsushi P. Kimura ${ }^{\mathrm{a}, \mathrm{b}, *}$

4

$5 \quad{ }^{\mathrm{a}}$ Graduate School of Life Science, Hokkaido University, Sapporo 060-0810, Japan

$6 \quad{ }^{b}$ Department of Biological Sciences, Faculty of Science, Hokkaido University, Sapporo 060-0810, Japan

7

8 *Corresponding author: Atsushi P. Kimura, Department of Biological Sciences, Faculty of Science,

9 Hokkaido University, Sapporo 060-0810, Japan. Phone and Fax: 81-11-706-4452. E-mail:

10 akimura@sci.hokudai.ac.jp

11

12

Disclosure summary: The authors certify that they have nothing to disclose.

13 


\section{$1 \quad$ Abstract}

2

3 Prolyl oligopeptidase (POP) is a serine endopeptidase which selectively digests a -Pro-X-peptide bond.

4 Our previous study showed that POP mRNA was strongly expressed in the spongiotrophoblast of the

5 mouse placenta at E17.5, suggesting its importance in development. To gain more insight into POP's role

6 during gestation, we investigated its expression using different developmental stages of placenta. As a

7 result of in situ hybridization, we found that localization of POP mRNA changed at E12.5. POP mRNA

8 was strongly expressed in the spongiotrophoblast and labyrinth at E10.5 and E11.5 but thereafter only in

9 the spongiotrophoblast. Immunohistochemistry revealed that POP was present in the parietal trophoblast

10 giant cell, the spongiotrophoblast cell, and the labyrinth at E11.5 but the strong expression in the labyrinth

11 was maintained only in the canal-associated and sinusoidal trophoblast giant cells at E16.5 and E18.5. To

12 determine subcellular distribution of the POP protein, we fractionated the placental extract into

13 cytoplasmic, membrane, and nuclear subfractions. By Western blot analysis, POP was detected in the

14 cytoplasmic and membrane fractions but not in the nuclear fraction at E11.5 and E16.5. Interestingly, the

15 cytoplasmic POP exhibited higher enzymatic activity than the membrane-associated type. These data

16 suggest that the cytoplasmic and membrane-associated POP have distinct roles in different types of

17 placental cells.

19 Key words: prolyl oligopeptidase, localization, placenta, spongiotrophoblast, trophoblast giant cell, subcellular distribution 
1 Abbreviations: ANOVA, analysis of variance; C-TGC, canal-associated TGC; E, embryonic day; MCA,

2 4-methylcoumaryl-7-amide; DTT, dithiothreitol; $\alpha \mathrm{MSH}, \alpha$-melanocyte stimulating hormone; PAGE,

3 polyacrylamide gel electrophoresis; PBS, phosphate-buffered saline; POP, prolyl oligopeptidase; P-TGC,

4 parietal TGC; PVDF, polyvinylidene difluoride; SD, standard deviation; SDS, sodium dodecyl sulfate;

5 S-TGC, sinusoidal TGC; SpA-TGC, spiral artery-associated TGC; TGC, trophoblast giant cell; PBST,

$6 \quad$ PBS containing $0.1 \%$ Tween 20

7 
Prolyl oligopeptidase (POP, E.C.3.4.21.26, prolyl endopeptidase, post proline cleaving enzyme; gene symbol Prep) is a serine endopeptidase which hydrolyzes a peptide bond at carboxyl side of an internal proline residue (Wilk, 1983). POP has an ancient origin and is distributed in various species from bacteria to mammals (Garcia-Horsman et al., 2007), and in higher organisms most tissues express it at different levels (Myöhänen et al., 2009). Because of its peculiar activity and wide distribution, the physiological role of POP has received intense interest since its discovery in 1971 (Walter et al.). The most studied tissue is the brain because POP has been reported to be related to learning and memory and may be a cause of some neurodegenerative diseases such as bipolar disorder and Alzheimer disease (Garcia-Horsman et al., 2007; Myöhänen et al., 2009; Williams, 2004). With regard to this, POP-deficient mice exhibited a defect in growth cone dynamics of neurons (Di Daniel et al., 2009). In pituitary, POP has been shown to process $\alpha$-melanocyte stimulating hormone ( $\alpha \mathrm{MSH})$ and affect obesity (Perroud et al., 2009; Warden et al., 2009). POP has also been suggested to be involved in cell proliferation and differentiation in murine Swiss 3 T3 cells (Ishino et al., 1998) and Sarcophaga peregrina (flesh fly) (Ohtsuki et al., 1994, 1997), but its physiological function still needs to be explored. Another important issue about POP is the subcellular localization. POP had been thought to be a cytosolic protein, but a membrane-bound form was recently purified from porcine brain and characterized (Tenorio-Laranga et al., 2008). Other results have suggested the existence of a secreted form (Kimura et al., 1998, 2002; Soeda et al., 1984; Takahashi et al., 1996), and in mammalian cultured cells and some mouse peripheral tissues, POP was also localized to the nucleus (Ishino et al., 1998; Myöhänen et al., 2008c). Therefore, POP is now thought to be present in various forms although it is encoded by a single gene (Kimura et al., 1999; Kimura and Takahashi, 2000). This is consistent with a recent report indicating that POP was associated with the cytoplasm, nucleus, and membrane in the cerebellar granule cell culture 
POP is commonly present in many tissues of many species.

The nuclear POP is often linked to development and differentiation. The POP enzymatic activity or its mRNA expression have been reported to be high at early developmental stages of the rat brain (Kato et al., 1980; Fuse et al., 1990; Yamanaka et al., 1999; Agirregoitia et al., 2003, 2010), pituitary (Agirregoitia et al., 2003), and liver (Matsubara et al., 1998) as well as of the mouse testis (Kimura et al., 2002). Because these stages are when cells proliferate and differentiate in each tissue, POP is presumed to be involved in cell cycle regulation and the nuclear POP is believed to be responsible for this role. In fact, a very recent report showed that POP was localized to the nucleus only early in the brain development (Hannula et al., 2010). Although there is no conclusive evidence for the nuclear POP controlling the cell cycle, it is widely accepted that POP plays some important roles in development and differentiation. Consistent with this, we observed a relatively high level of POP mRNA expression in the mouse embryo during early gestation (Matsubara et al., 2010).

The placenta plays a critical role in fetal development by forming an interface between the maternal and fetal circulation. The developed mouse placenta is mainly composed of three layers: the outer maternal decidua, middle junctional zone, and innermost labyrinth layer. The maternal decidua contains decidual cells, which originate from the uterus, and maternal vasculature to transport blood to the fetus. The labyrinth layer includes highly branched maternal and fetal vasculatures composed of several distinct cell types for efficient exchange of nutrients and gases. Separating these two, the junctional zone consisting of the spongiotrophoblast and glycogen trophoblast cell supports the labyrinth structurally and functionally by producing many angiogenic and tissue remodeling factors (Rossant and Cross, 2001). In addition, the mouse placenta includes four subtypes of trophoblast giant cells (TGCs) that play important roles in the maintenance of pregnancy by secreting many hormones and paracrine factors (Hu and Cross, 2010; Simmons et al., 2007). Parietal TGC (P-TGC) positions between the maternal decidua and junctional zone, and spiral artery-associated TGC (SpA-TGC) lines maternal spiral arteries in the decidua. Canal-associated TGC (C-TGC) and sinusoidal TGC (S-TGC) are found in the labyrinth. Many genes are 
Detection of RNA

thought to be involved in the regulation of placental functions (Watson and Cross, 2005) but the molecular mechanisms are still poorly understood.

In the mouse, POP mRNA is highly expressed in the ovary and placenta (Matsubara et al., 2010), suggesting its importance in reproduction and development. As an initial step toward understanding the physiological function of POP in development, here we investigated its expression and localization in different developmental stages of placenta. We found that the localization of POP mRNA and protein changed at embryonic day (E)12.5. POP was strongly expressed in P-TGCs, spongiotrophoblast cells, and the labyrinth layer before E12.5, but only C-TGCs and S-TGCs maintained the strong expression in the labyrinth after that. We also assessed the subcellular distribution of POP in the placenta and found that POP was localized in the cytoplasm and membrane but not in the nucleus. These results suggest that the distinct forms of POP contribute to different placental functions.

\section{Materials and methods}

Animals and tissue preparation

C57/BL6 and BDF1 (C57/BL6 × DBA2 F1) mice were obtained from CLEA Japan Inc. (Tokyo, Japan) and maintained under standard conditions, with free access to food and water, and a 14-h light/10-h dark cycle. Tissues were collected as previously described (Matsubara et al., 2010). All the placentas were isolated with the maternal decidua. The experimental procedures used in this study were approved by the Institutional Animal Use and Care Committee at Hokkaido University. 
$4 \quad$ POP activity assay et al., 2010).

We homogenized each placenta (E10.5-E18.5) in ice-cold phosphate-buffered saline (PBS). The

homogenate was centrifuged at $15,000 \mathrm{rpm}$ for $5 \mathrm{~min}$ at $4^{\circ} \mathrm{C}$ and the supernatant was used for the enzymatic activity assay. The subcellular fractions were prepared as below. The specific POP activity toward Suc-Gly-Pro-Leu-Gly-Pro-4-methylcoumaryl-7-amide (MCA; Peptide Institute, Osaka, Japan) was measured as previously described (Kimura et al., 1998).

Expression and purification of recombinant mouse POP

An open reading frame of mouse POP was subcloned into pET30a expression vector (Novagen, Medison, WI) (Kimura et al., 2002). Expression of the recombinant mouse POP in the Escherichia coli expression system was carried out according to the method of Ogiwara et al. (2005). The recombinant POP was produced as a fusion protein with a vector-derived N-terminal sequence containing His-tag and an S-protein. Harvested cells were suspended in $0.1 \mathrm{M}$ Tris- $\mathrm{HCl}(\mathrm{pH} 8.0)$, lysed by freeze-thaw method, sonicated, and centrifuged at $9,000 \mathrm{rpm}$ for $15 \mathrm{~min}$ at $4^{\circ} \mathrm{C}$. The supernatant was filtered with Minisart filter unit ( $0.45 \mu \mathrm{m}$ pore size, Sartorius Biolab Products, Goettingen, Germany) and subjected to $\mathrm{Ni}^{2+}$ affinity chromatography (GE Healthcare Biosciences, Piscataway, NJ). The recombinant POP was eluted with the buffer containing $50 \mathrm{mM}$ histidine. In order to remove an extra amino acid sequences, approximately $650 \mu \mathrm{g}$ of the POP protein was incubated with $3 \mu$ of medaka enteropeptidase in Enteropeptidase Buffer (20 mM Tris- $\left.\mathrm{HCl}, 50 \mathrm{mM} \mathrm{NaCl}, 2 \mathrm{mM} \mathrm{CaCl}_{2}, \mathrm{pH} 7.4\right)$ for $16 \mathrm{~h}$ at $26^{\circ} \mathrm{C}($ Ogiwara and Takahashi, 2007). Then the recombinant POP was separated on a Resource Q column with AKTA 
Purifier (GE Healthcare Biosciences) in $50 \mathrm{mM}$ Tris- $\mathrm{HCl}$ (pH 8.0) and fractions with high POP activity were collected. After the removal of the extra peptide using the $\mathrm{Ni}^{2+}$ sepharose column, the recombinant POP was further purified by Mono Q column with AKTA Purifier (GE Healthcare Biosciences) in $50 \mathrm{mM}$ Tris- $\mathrm{HCl}(\mathrm{pH}$ 8.0). We confirmed a single band of the recombinant POP by sodium dodecyl sulfate-polyacrylamide gel electrophoresis (SDS-PAGE) and Coomassie Brilliant Blue staining. To exchange the buffer at each step, we used VIVASPIN 20 centrifugal concentrator (10,000 MWCO, PES, Sartorius Biolab Products).

Generation and purification of polyclonal anti-POP antibody

We obtained approximately $3.5 \mathrm{mg}$ purified recombinant POP protein from about 20 litters of the bacterial culture. Two hundred micrograms of the protein were injected into a chicken every two weeks and the antiserum was checked by Western blot analysis at 5 and 10 weeks after the first injection. Specific anti-POP antibody was purified from the serum by the method using Western blot. We injected the antigen into three chickens $(\mathrm{C} 1, \mathrm{C} 2, \mathrm{C} 3)$ and the antiserum from the $\mathrm{C} 1$ chicken was used in this study. Excess amount of the recombinant POP was separated by SDS-PAGE and blotted to the polyvinylidene difluoride membrane (PVDF, Millipore, Bedford, MA). After the position of the POP signal was confirmed by staining the $1 \mathrm{~cm}$ side of the membrane, the band including POP was cut out from the remaining membrane. Blocking was conducted as below and the membrane was incubated for overnight at $4^{\circ} \mathrm{C}$ with $500 \mu \mathrm{l}$ antiserum combined with the same volume of PBS containing $0.1 \%$ Tween 20 (PBST). The membrane was washed with PBST for 10 min three times and incubated with $10 \mathrm{ml}$ of Elution Buffer (0.1 M Glycine-HCl, $0.5 \mathrm{M} \mathrm{NaCl}, \mathrm{pH} 2.4)$ for 20 min with shaking. The eluted antibody was neutralized by adding $2 \mathrm{ml}$ of $2 \mathrm{M}$ Tris- $\mathrm{HCl}$ ( $\mathrm{pH} 8.0$ ). The buffer was exchanged to PBS and the antibody was concentrated to $200 \mu \mathrm{l}$ by using VIVASPIN 20 (Sartorius Biolab Products). The antibody was mixed with the same volume of glycerol and stored at $-20^{\circ} \mathrm{C}$ until use. The antibody concentration was determined 
$3 \quad$ Western blot analysis

Twenty micrograms of each sample was electrophoresed on an $8 \%$ SDS-PAGE gel and blotted to a PVDF membrane (Millipore). After blocking with Block Ace (Dainippon Seiyaku) and normal rabbit serum (1:250 dilution with PBST) for $1 \mathrm{~h}$ each at room temperature, the membrane was incubated with the antibody for $1 \mathrm{~h}$ at room temperature. The antibodies used in this study were the purified anti-POP antibody (10 $\mu \mathrm{g} / \mathrm{ml}$ at a final concentration), anti- $\beta$-actin monoclonal antibody (1:1000 dilution, Sigma, St Louis, MO), anti-histone H3 antibody (1:100 dilution) (Kimura et al., 2008), and anti-connexin 43 antibody (1:500 dilution, Transduction Laboratories, Lexington, KY). The antibodies for POP were diluted with ExactaCruz ${ }^{\mathrm{TM}}$ E Dilution Buffer (Santa Cruz Biotechnology, Santa Cruz, CA), and for $\beta$-actin, histone $\mathrm{H} 3$, and connexin-43 with PBST. The membrane was further incubated for $1 \mathrm{~h}$ at room temperature with the secondary antibody, goat anti-chicken IgY antibody (1:10000 dilution, Jackson ImmunoResearch, West Grove, PA) for POP and anti-mouse IgG antibody (1:5000 dilution, GE healthcare) for the other antibodies. The signals were detected using an Immobilon Western Chemiluminescent HRP Substrate (Millipore) according to the manufacture's instruction. To confirm the specificity of the generated antibody, we conducted the same experiment by using the POP antibody preincubated with the purified recombinant POP. Immunohistochemistry Placentas were fixed at $4{ }^{\circ} \mathrm{C}$ for overnight in Bouin's solution, embedded in paraffin, and sectioned at $6 \mu \mathrm{m}$. The sections were dewaxed in xylene for $10 \mathrm{~min}$ and rehydrated in serial ethanol solution and running tap water. The slides were boiled using a microwave oven in $10 \mathrm{mM}$ citric acid buffer (pH 6.0) 
for 5-10 min and cooled for $15 \mathrm{~min}$ at room temperature. Endogenous peroxidase activity was quenched by incubating the slides with $2.25 \%$ hydrogen peroxide for $15 \mathrm{~min}$. After being washed with running tap water and PBS for 5 min each, the slides were blocked as in Western blot. The sections were incubated with the prurified anti-POP antibody ( $40 \mu \mathrm{g} / \mathrm{ml}$ at a final concentration) for $12 \mathrm{~h}$ at room temperature and washed with PBS for 5 min three times. After being incubated with the secondary anti-chicken IgY antibody (1:500 dilution) for $3 \mathrm{~h}$ at room temperature and washed with PBS, the signals were developed using AEC Peroxidase Substrate kit (Vector Labolatories, Inc., Burlingam, CA) for 20-30 min. For negative controls, slides were incubated without the primary antibody or with the POP antibody preincubated with the purified recombinant POP at that step. After the signal was developed, the sections were counterstained with Carazzi's hematoxylin for $5 \mathrm{~min}$.

Preparation of subcellular fractions

To obtain subcellular fractions from the placenta, we applied two different methods. The first one was to separate the cytoplasmic and membrane subfractions from the nuclear subfraction. We homogenized the placenta at E10.5 and E15.5 in $1 \mathrm{ml}$ of ice-cold Sucrose Buffer I ( $0.32 \mathrm{M}$ sucrose, $3 \mathrm{mM}$ $\mathrm{CaCl}_{2}, 2 \mathrm{mM}$ magnesium acetate, $0.1 \mathrm{mM}$ EDTA, $10 \mathrm{mM}$ Tris-HCl, $1 \mathrm{mM}$ dithiothreitol (DTT), $0.5 \mathrm{mM}$ phenylmethylsulfonyl fluoride, $0.5 \% \mathrm{NP}-40, \mathrm{pH} 8.0$ ) and the homogenates were centrifuged at 3,000 rpm for $5 \mathrm{~min}$ at $4{ }^{\circ} \mathrm{C}$. The supernatant contained cytoplasmic and membrane-associated proteins and the precipitate was the nucleus. We collected the supernatant by adding $220 \mu \mathrm{l}$ of $5 \times$ Extraction Buffer $(0.15$ M HEPES-KOH, $0.7 \mathrm{M} \mathrm{KCl}, 15 \mathrm{mM} \mathrm{MgCl} 2, \mathrm{pH} 7.9$ ) and centrifuging it at $12,000 \mathrm{rpm}$ for $15 \mathrm{~min}$ at $4^{\circ} \mathrm{C}$ (designated as ' $\mathrm{C}+\mathrm{M}$ '). The nucleus was suspended in $1 \mathrm{ml}$ of Sucrose Buffer I lacking NP-40 and centrifuged at $3,000 \mathrm{rpm}$ for $5 \mathrm{~min}$ at $4{ }^{\circ} \mathrm{C}$. The precipitates were resuspended in $200 \mu \mathrm{l}$ of Low-Salt Buffer (20 mM HEPES-KOH, 25\% Glycerol, $1.5 \mathrm{mM} \mathrm{MgCl} 2,20 \mathrm{mM} \mathrm{KCl,} 0.2 \mathrm{mM}$ EDTA, $0.5 \mathrm{mM}$ DTT, pH 7.9), and the same volume of High-Salt Buffer (20 mM HEPES-KOH, $25 \%$ Glycerol, $1.5 \mathrm{mM} \mathrm{MgCl}$, 
$1 \quad 0.8 \mathrm{M} \mathrm{KCl}, 0.2 \mathrm{mM}$ EDTA, $0.5 \mathrm{mM}$ DTT, pH 7.9) was mixed with the nucleus by adding $50 \mu l$ four times.

2 The total volume of $400 \mu \mathrm{l}$ including the nuclear protein were incubated for $20 \mathrm{~min}$ at $4^{\circ} \mathrm{C}$ with gentle

3 rotation and then $800 \mu \mathrm{l}$ of Diluent (25 mM HEPES, 0.1 mM EDTA, $0.5 \mathrm{mM}$ DTT, pH 7.6) were added.

4 After centrifugation at $15,000 \mathrm{rpm}$ for $15 \mathrm{~min}$ at $4^{\circ} \mathrm{C}$, the supernatants were collected (designated as ' $\mathrm{N}$ ').

5 The second procedure was to prepare the cytoplasmic, membrane, and nuclear subfractions

6 separately. The experiment was performed as described by others with slight modifications (Ogiwara and

7 Takahashi, 2007). We homogenized the placenta at E11.5 and E16.5 in $1 \mathrm{ml}$ of ice cold buffer A (10 mM

8 Tris- $\mathrm{HCl}, 10 \mathrm{mM} \mathrm{MgCl}_{2}, 10 \mathrm{mM} \mathrm{KCl}, 1 \mu \mathrm{M}$ DTT, $\mathrm{pH}$ 7.5) containing $1 \times$ proteinase inhibitor cocktail

9 (Roche Molecular Biochemicals, Mannheim, Germany) and centrifuged the homogenate at $1,600 \times g$ for

$108 \mathrm{~min}$ at $4^{\circ} \mathrm{C}$. The precipitate was treated as in the first method and the obtained extract was designated as

11 the nuclear subfraction $(\mathrm{N})$. The supernatant was further centrifuged at $100,000 \times g$ at $4^{\circ} \mathrm{C}$ for 30 min and the resulting supernatant was the cytoplasmic subfraction (C). The precipitate was washed with $1.5 \mathrm{ml}$ of $0.1 \mathrm{M}$ Tris- $\mathrm{HCl}(\mathrm{pH} 8.0)$, centrifuged again at $100,000 \times g$ at $4^{\circ} \mathrm{C}$ for $30 \mathrm{~min}$, and suspended in $0.1 \mathrm{M}$ Tris-HCl (pH 8.0) (M). All samples were sonicated using a Tomy Ultrasonic Disrupter UD-201 (Tomy, Tokyo,Japan) with $20 \%$ output for 5 s 3 times.

Results were expressed as the average \pm standard deviation (SD) of at least three independent experiments and analyzed by Student's $t$ test or one-way analysis of variance (ANOVA) followed by Tukey's post hoc test using JSTAT statistical software (version 12.6 for Windows, Masato Sato, Japan).

\section{Results}


2 Tissue distribution of POP mRNA and its localization in the placenta.

We previously showed that the ovary and placenta expressed a higher level of POP mRNA than the liver, testis, and uterus (Matsubara et al., 2010). We extended this analysis to 16 mouse tissues and performed a Northern blot analysis. Although the lung RNA seemed to be degraded, the result indicated that the ovary and placenta expressed the highest level of POP mRNA in the tissues (Fig. 1). We then investigated the localization of POP mRNA in the placenta at E10.5-E18.5. Consistent with our previous result of the E17.5 placenta (Matsubara et al., 2010), POP mRNA was strongly expressed in the spongiotrophoblast at E12.5-E18.5 (Fig. 2A). However, in the E10.5 and E11.5 placenta, a strong signal was detected in both the spongiotrophoblast and the labyrinth layer (Fig. 2A). Higher magnification images of the E11.5 and E15.5 placenta, which represent the two types of staining patterns, suggested that S-TGC was the only cell type that maintained the POP mRNA expression in the labyrinth at E15.5 (Fig. 2B). We could also identify P-TGC in the junctional zone which was stained at both E11.5 and E15.5 and the decidual cell was weakly stained in both the placentas (Fig. 2B). Flt1 was used as a marker of the spongiotrophoblast in the neighboring section (Hitz et al., 2005). No positive signal was obtained in the sections hybridized with POP and Flt1 sense probes (Fig. 2A). Sections stained with hematoxylin and eosin were provided to show the morphology of each region of the placenta (Fig. 2B). The data indicated that the mouse placenta expressed a high level of POP mRNA and its localization changed at E12.5. Placental POP activity and protein amount during gestation. activity and performing Western blot analysis (Fig. 3). We prepared soluble extracts from E10.5-E18.5 
1 POP is the only known enzyme that can digest this substrate. The result showed that the activity gradually increased about 2-fold between E10.5 and E14.5 and the high level of activity was kept until E18.5 (Fig. 3A). For Western blot analysis, we generated and purified the POP antibody as described in materials and methods. We first used the extracts of the brain and E18.5 placenta for the analysis and detected a single band at $72 \mathrm{kDa}$ (Fig. 3B, left). To confirm the specificity of the 72-kDa band, we conducted the same experiment by using the POP antibody preincubated with the recombinant POP and this resulted in disappearance of the band (Fig. 3B, right). The data indicates that the POP antibody we generated specifically recognizes the POP protein. We then assessed the POP protein expression in E10.5-E18.5 placentas by using $\beta$-actin as a loading control and found that it was present at a constant level during this period (Fig. 3C, D). This is in agreement with the profile of the POP mRNA level, which was also constant during the same period (Matsubara et al., 2010), but is not consistent with the POP activity (Fig. $3 \mathrm{~A})$.

Localization of POP protein in the placenta.

To identify the cell type expressing POP protein, we next conducted the immunohistochemisty using E11.5, E16.5, and E18.5 placentas. We chose the E11.5 and E16.5 placenta as representative stages of the two expression patterns of POP mRNA (Fig. 2) and the E18.5 placenta as a fully mature stage. The strong POP signal was detected in the junctional zone and the labyrinth layer in the E11.5 placenta but the signal in the labyrinth dramatically decreased at E16.5 and E18.5 (Figs. 4A, 5A, M). Higher magnification of figures showed that all P-TGCs and spongiotrophoblast cells strongly expressed POP protein at the three stages (Figs. 4C, D, 5C, D, O-R). Glycogen trophoblast cells, which appear after E12.5 (Simmons and Cross, 2005), were very weakly stained in the E16.5 or E18.5 placentas (Fig. 5I, J, Q, R). The labyrinth layer contains several types of cells such as syncytiotrophoblast cells, the fetal vascular endothelium, and the allantois as well as S-TGCs and C-TGCs. In the E11.5 placenta, most labyrinthine cells showed a 
positive POP signal and the only exception was the allantois (Fig. 4E, F). By contrast, we observed a strong POP signal almost exclusively in S-TGCs and C-TGCs in the labyrinth at E16.5 and E18.5 (Fig. 5E-H, S-V). The allantois was negative for POP immunoreactivity at these two stages, too (Fig. 5K, L, S, T). In the E18.5 placenta, we could also identify SpA-TGCs, which were stained (Fig. 5W, X). The maternal decidua showed weak POP immunoreactivity at all the stages examined (Figs. 4A, 5A, M). No signal was observed in any placental cells on the control sections treated without the POP antibody (data not shown) or with the POP antibody preincubated with the purified recombinant POP (Figs. 4B, 5B, N). The results of our immunohistochemistry are summarized in Table 1 . These data suggest that POP protein is strongly expressed in the S-TGC, P-TGC, the spongiotrophoblast cell, and most cells of the labyrinth layer before E12.5 and in the spongiotrophoblast and four subtypes of TGCs after that. Interestingly, the signal seemed to be localized in the cytoplasm of all the POP-positive cells at all the stages examined.

Subcellular distribution of placental POP.

The immunohistochemistry suggested that POP protein was localized in the cytoplasm of all the POP-expressing placental cells. However, we could not tell whether the POP protein is associated with membrane or not. Therefore, we fractionated the placental extract into cytoplasmic, membrane, and nuclear subfractions. We applied two different methods to the fractionation. In the first method, we separated the combined cytoplasmic and membrane extract $(\mathrm{C}+\mathrm{M})$ from the nuclear extract $(\mathrm{N})$ to confirm that POP was not localized to the nucleus. We checked the POP activity of each fraction and found that the $\mathrm{C}+\mathrm{M}$ fraction had high POP activity in both the E10.5 and E15.5 placentas, whereas no significant activity was detected in the $\mathrm{N}$ fraction (Fig. 6A). Western blot analysis demonstrated that POP protein exists only in the $\mathrm{C}+\mathrm{M}$ fraction (Fig. $6 \mathrm{~B}$ ). The results indicated that the placental POP protein was not localized to the nucleus. 
1 As a result of the enzymatic activity assay, the cytoplasmic extract showed much higher POP activity than

2 the other two fractions in both E11.5 and E16.5 placentas (Fig. 6C). Interestingly, the membrane

3 subfraction still showed higher POP activity than the nuclear extract, although the difference was not

4 statistically significant. By Western blot analysis, we observed a POP signal in both the cytoplasmic and

$5 \quad$ membrane fractions but not in the nuclear fraction (Fig. 6D). Antibodies against histone $\mathrm{H} 3$ and

6 connexin- 43 were used as markers of the nucleus and plasma membrane respectively and the results

7 confirmed that our fractionation was successful (Fig. 6D). To compare the POP activity in the cytoplasm

8 and membrane, we repeated Western blot analysis three times and quantified each signal by using the

9 Image J software to normalize the POP band intensity to $\beta$-actin. As a result, the amounts of cytoplasmic

10 POP in E11.5 and E16.5 placentas were 2.3- and 3.3-fold higher, respectively, than in the membrane-associated POP (Fig. 6D). Because the activities of the cytoplasmic extracts in E11.5 and E16.5 placentas were 15.3- and 12.7-fold higher, respectively, than in the membrane fractions (Fig. 6C), the activity of the cytoplasmic POP was probably higher than that of the membrane-associated POP.

14 These results indicated that placental POP was localized in the cytoplasm and membrane, and that the membrane type seemed to have lower enzymatic activity.

\section{Discussion}

Tissue distribution of POP. placenta expressed relatively high levels of POP mRNA (Fig. 1). This appears to be inconsistent with several studies reporting that the brain contained higher POP activity than other tissues (Fuse et al., 1990; 
assay and one report indicated that the ovary contained higher POP activity than the brain in the mouse

2 (Ohta et al., 1992). In addition, many reports have suggested that POP enzymatic activity is not necessarily consistent with its mRNA level and protein amount (Bellemère et al., 2004; Garcia-Horsman et al., 2007; Irazusta et al., 2001; Myöhänen et al., 2007, 2008a,b), possibly due to post-transcriptional or post-translational modifications or the existence of endogenous POP inhibitors (Salers, 1994; Soeda et al., 1985). Thus, what we can say from the current study is that at least in the mouse, POP mRNA is expressed at higher levels in the ovary and placenta than the brain. mRNA was reported to be expressed at the highest level in the skeletal muscle but at low levels in the ovary and placenta (Goossens et al., 1997; Shirasawa et al., 1994). In the rat, the brain expressed a relatively high level of POP mRNA although the study included neither the ovary nor the placenta (Kimura and Takahashi, 2000). Porcine POP mRNA was expressed at much higher levels in the heart and muscle than the ovary (Rennex et al., 1991). These indicate that the tissue expressing POP mRNA at a high level is different between species and suggest that POP may have different roles in various species.

Molecular mass of POP.

We generated the new POP antibody which detected a 72-kDa band as the mouse POP protein (Fig. 3B, D). The mammalian POP protein consists of 710 amino acids with a calculated molecular mass of 80.7 kDa and indeed the POP antibody generated by another group detected rat and human POP at $80 \mathrm{kDa}$ (Myöhänen et al., 2007). However, POP protein purified from many mammalian tissues has been reported to be $65-80 \mathrm{kDa}$ (Welches et al., 1993), suggesting that the molecular mass of POP might be different between species or tissue types. Alternatively, some post-translational modifications might affect the electromobility or even the difference of marker proteins might result in the difference of the calculated molecular mass. In any case, because we could confirm the specificity of the detected band by 
preincubation of the antibody with the purified POP, we concluded that the antibody specifically recognized the mouse POP protein at $72 \mathrm{kDa}$ in our hands.

Localization of POP in the mouse placenta.

(1)

We investigated the localization of POP mRNA and protein in the developing mouse placenta. Using immunohistochemistry, we determined many cell types by morphology, but using in situ hybridization, we could not do so because the cell morphology seemed to be modified in our cryosections, for unknown reasons. While we observed strong POP immunoreactivity in spongiotrophoblast cells and four subtypes of TGCs at E16.5 and E18.5 and in other labyrinthine cells besides those at E11.5 (Figs. 4, 5), we could only identify the spongiotrophoblast, P-TGC, and S-TGC by in situ hybridization (Fig. 2). Nevertheless, the two data sets of the POP mRNA and protein localization are similar in that 1) spongiotrophoblast cells and P-TGCs were strongly stained at all the stages examined, 2) in the labyrinth, most cells were strongly stained before E12.5 but only TGCs were thereafter, and 3) the decidual cell was weakly stained at all the stages. These indicate that the localization of POP mRNA and protein was generally consistent with each other. It is assumed that POP is strongly expressed in the spongiotrophoblast cell and all subtypes of TGCs at E10.5-E18.5 while in the labyrinth most cells express POP at E10.5 and E11.5 but the strong expression is maintained only in the S-TGC and C-TGC after that.

An interesting finding was that POP localization changed at E12.5 in the placenta. POP was presumably down-regulated in the labyrinthine cells other than TGCs such as syncytiotrophoblast and fetal vascular endothelial cells. This suggests that POP in these cells have distinct roles from POP in other cells and is involved in some events taking place around E10-E12. For example, POP might degrade some peptides that are present only around these stages. It might also be related to differentiation of some placental cells including the syncytiotrophoblast (Rossant and Cross, 2001) or play some role in the establishment of fetal-maternal connection (Adamson et al., 2002). In contrast, POP in the 
spongiotrophoblast and TGCs might be involved in the secretion of hormones and growth factors because

2 POP was suggested to control protein secretion in human glioma cells (Schulz et al., 2005). Alternatively,

3 POP might participate in the processing of hormones and growth factors that the spongiotrophoblast and

4 TGCs secrete. Considering that the overall POP activity increased during the placental development (Fig.

$53 \mathrm{~A}$ ), more POP activity might be required in the spongiotrophoblast and TGCs at later gestation.

To reveal the physiological role of POP in mouse development, the identification of physiological substrates is of great importance. The only peptide proven to be an in vivo substrate of POP is $\alpha-\mathrm{MSH}$ in the mouse pituitary (Perroud et al., 2009) and it is actually known to be present in the placenta (Krieger, 1982). In addition, some proline-containing bioactive peptides in the placenta, such as substance $\mathrm{P}$, angiotensin II, and oxytocin, could be substrates of POP (Gimpl et al., 2001; Marzioni et al., 2005; Walther et al., 2008). Taking into account that POP is the only enzyme capable of hydrolyzing a peptide containing proline residues, it should be indispensable for its processing or degradation. However, POP-deficient mice reported by two groups seem to be normal in terms of reproduction and development (Di Daniel et al., 2009; Warden et al., 2009), indicating that the accumulation of proline-containing peptides was not toxic to murine cells. This suggests that POP may not be very important for normal reproduction and development and it may instead play an essential role in disease prevention or stress response. More detailed analyses of the knockout mice or other strategies will be required to reveal the POP's role in reproduction and development.

Subcellular distribution of POP.

We have also assessed subcellular localization of POP and found that POP was associated with the cytoplasm and membrane in the placenta. This was based on the observation that there was no POP-immunoreactivity in the nuclei of any placental cells (Fig. 4, 5), and that no POP protein signals and no enzymatic activities were detected in the placental nuclear fractions prepared by two different methods 
1 (Fig. 6). Although we can not completely rule out the possibility that a few placental cells contain the

2 nuclear POP or many placental cells contain a very low level of POP in the nuclei, the results indicate that

3 POP is predominantly localized to the cytoplasm and membrane in the mouse placenta.

Several immunohistochemical studies reported the subcellular distribution of POP and showed that in addition to the cytoplasm, POP was localized to the membrane of neurons and to the nucleus in some cultured cells and peripheral tissues (Myöhänen et al., 2008c; Schulz et al., 2005). More detailed studies reported that POP was associated with microtubules in the perinuclear cytoplasm in glioma cells (Schulz et al., 2005) and was attached to rough endoplasmic reticulum and Golgi apparatus in the rat brain (Myöhänen et al., 2008b). These data indicate that the subcellular distribution of POP is different among tissues and cells and suggest that POP has distinct roles in various tissues and cells.

It is notable that POP is not localized to the nucleus in the developing mouse placenta because the nuclear POP is thought to be involved in the regulation of cell proliferation and differentiation. This role of POP was first suggested by the finding that a specific POP inhibitor, ZTTA, inhibited DNA synthesis in the cultured cells of flesh fly and mouse and POP was localized to the nuclei in the cells (Ishino et al., 1998; Ohtsuki et al., 1997). Some of the recent studies also support this function by showing that POP was localized to the nucleus in proliferating or differentiating cells (Hannula et al., 2010; Moreno-Baylach et al., 2008). However, no particular mechanisms have yet been suggested, so it may also be possible that the cytoplasmic and membrane-associated POP could participate in cell cycle regulation. In fact, many proteins controlling the cell cycle are known to be localized to the cytoplasm although the proteins involved in DNA synthesis are usually localized to the nucleus (Besson et al., 2008; Kahl and Means, 2003; Sclafani and Holzen, 2007; Wilkinson and Millar, 2000). In case of the mouse placenta, the cytoplasmic POP may play some role in cell cycle regulation, for example, by processing or interacting with other proteins involved in the cell cycle. Alternatively, the mouse placental POP may not even be involved in cell proliferation and have other roles. 
Enzymatic activity of cytoplasmic and membrane-associated POP.

It is interesting that the cytoplasmic POP had a higher enzymatic activity than the membrane-associated form, which is consistent with previous reports (Agirregoitia et al., 2003; Irazusta et al., 2002; Tenorio-Laranga et al., 2008). The cytoplasmic POP was found in every placental cell by immunohistochemistry, suggesting that it has a common function to many cells. The involvement in intracellular protein degradation is one possibility. In this case, high POP activity is probably necessary because there are many proline-containing peptides inside the cell and POP is the only enzyme to degrade them. In contrast, the membrane-associated POP may have different roles. In our current protocol, the membrane fraction could contain not only the plasma membrane but also other membranes such as the endoplasmic reticulum and Golgi apparatus, so it could function in either intracellular or extracellular environment. Considering that a previous study found POP localized to intracellular membranes rather than the plasma membrane in neurons (Myöhänen et al., 2008b), and that we did not observe any strong POP immunoreactivity in the plasma membrane, the membrane form of POP is more likely to function inside the cell. Because intracellular POP has been reported to interact with other proteins and be able to function without its peptidase activity (Di Daniel et al., 2009; Schulz et al., 2005), the placental membrane POP may work irrespective of its enzymatic activity. If the membrane POP works extracellularly, it could directly contact maternal blood in some TGCs and might process or digest bioactive peptides in the blood. The lower POP activity in the membrane fraction might be a result of the existence of various types of membrane POP possessing different activities. Further analysis will be required for revealing the functions of the two forms of POP in different placental cells.

\footnotetext{
In conclusion, this work analyzed the temporal and spatial POP expression in the mouse placenta.
}

We determined the cell type expressing POP and found that the localization of POP becomes restricted to the spongiotrophoblast cells and TGCs throughout placental development. We also found that the 
placental POP was associated with the cytoplasm and membrane. These results suggest that the distinct

2 forms of POP have different roles in various placental cells.

3

4

5

6

7

8

\section{Acknowledgements}

We thank Dr. Hiroshi Kimura (Osaka University) for kindly gifting the antibody for histone H3. We also thank Dr. Katsueki Ogiwara (Hokkaido University) for helpful technical advice and critical reading of the manuscript. S.M. is a recipient of SUNBOR scholarship from SUNTORY Institute for Bioorganic Research, Japan. This work was supported by Grants-in-aid for Scientific Research 19770048 and 21770068 (A.P.K.) from the Ministry of Education, Culture, Sports, Science and Technology, Japan.

\section{References}

Adamson SL, Lu Y, Whiteley KJ, Holmyard D, Hemberger M, Pfarrer C, Cross JC (2002) Interactions between trophoblast cells and the maternal and fetal circulation in the mouse placenta. Dev Biol $250: 358-373$

Agirregoitia N, Bizet P, Agirregoitia E, Boutelet I, Peralta L, Vaudry H, Jégou S (2010) Prolyl endopeptidase mRNA expression in the central nervous system during rat development. J Chem Neuroanat 40:53-62

Agirregoitia N, Irazusta A, Ruiz F, Irazusta J, Gil J (2003) Ontogeny of soluble and particulate prolyl endopeptidase activity in several areas of the rat brain and in the pituitary gland. Dev Neurosci $25: 316-323$

Bellemère G, Vaudry H, Mounien L, Boutelet I, Jégou S (2004) Localization of the mRNA encoding 
prolyl endopeptidase in the rat brain and pituitary. J Comp Neurol 471:128-143

Besson A, Dowdy SF, Roberts JM (2008) CDK inhibitors: cell cycle regulators and beyond. Dev Cell

$$
\text { 14:159-169 }
$$

Di Daniel E, Glover CP, Grot E, Chan MK, Sanderson TH, White JH, Ellis CL, Gallagher KT, Uney J, Thomas J, Maycox PR, Mudge AW (2009) Prolyl oligopeptidase binds to GAP-43 and functions without its peptidase activity. Mol Cell Neurosci 41:373-382

Fuse Y, Polk DH, Lam RW, Reviczky AL, Fisher DA (1990) Distribution and ontogeny of thyrotropin-releasing hormone degrading enzymes in rats. Am J Physiol 259:E787-791

Garcia-Horsman JA, Männistö PT, Venäläinen JI (2007) On the role of prolyl oligopeptidase in health and disease. Neuropeptides 41:1-24

Gimpl G, Fahrenholz F (2001) The oxytocin receptor system: structure, function, and regulation. Physiol Rev 81:629-683

Goossens F, Vanhoof G, De Meester I, Augustyns K, Borloo M, Tourwe D, Haemers A, Scharpé S (1997) Development and evaluation of peptide-based prolyl oligopeptidase inhibitors--introduction of N-benzyloxycarbonyl-prolyl-3-fluoropyrrolidine as a lead in inhibitor design. Eur J Biochem 250:177-183

Hannula MJ, Männistö PT, Myöhänen TT (2010) Sequential expression, activity and nuclear localization of prolyl oligopeptidase protein in the developing rat brain. Dev Neurosci 33:38-47

Hersh LB (1981) Immunological, physical, and chemical evidence for the identity of brain and kidney post-proline cleaving-enzyme. J Neurochem 37:172-178

Hitz C, Vogt-Weisenhorn D, Ruiz P, Wurst W, Floss T (2005) Progressive loss of the spongiotrophoblast layer of Birc6/Bruce mutants results in embryonic lethality. Genesis 42:91-103

Hu D, Cross JC (2010) Development and function of trophoblast giant cells in the rodent placenta. Int J Dev Biol 54:341-354

Irazusta J, Larrinaga G, González-Maeso J, Gil J, Meana JJ, Casis L (2002) Distribution of prolyl 
endopeptidase activities in rat and human brain. Neurochem Int 40:337-345

Irazusta J, Silveira PF, Gil J, Varona A, Casis L (2001) Effects of hydrosaline treatments on prolyl endopeptidase activity in rat tissues. Regul Pept 101:141-147

Ishino T, Ohtsuki S, Homma K, Natori S (1998) cDNA cloning of mouse prolyl endopeptidase and its involvement in DNA synthesis by Swiss 3T3 cells. J Biochem 123:540-545

Kato T, Nakano T, Kojima K, Nagatsu T, Sakakibara S (1980) Changes in prolyl endopeptidase during maturation of rat brain and hydrolysis of substance P by the purified enzyme. J Neurochem $35: 527-535$

Kahl CR, Means AR (2003) Regulation of cell cycle progression by calcium/calmodulin-dependent pathways. Endocr Rev 24:719-736

Kimura A, Matsui H, Takahashi T (2002) Expression and localization of prolyl oligopeptidase in mouse testis and its possible involvement in sperm motility. Zool Sci 19:93-102

Kimura A, Ohnishi J, Okimura H, Hamabata T, Takahashi T (1998) Localization of prolyl endopeptidase mRNA in small growing follicles of porcine ovary. Mol Reprod Dev 50:121-127

Kimura A, Takahashi (2000) cDNA cloning of rat prolyl oligopeptidase and its expression in the ovary during the estrous cycle. J Exp Zool 286:656-665

Kimura A, Yoshida I, Takagi N, Takahashi T (1999) Structure and localization of the mouse prolyl oligopeptidase gene. J Biol Chem 274:24047-24053

Kimura H, Hayashi-Takanaka Y, Goto Y, Takizawa N, Nozaki N (2008) The organization of histone H3 modifications as revealed by a panel of specific monoclonal antibodies. Cell Struct Funct 33:61-73

Krieger DT (1982) Placenta as a source of 'brain' and 'pituitary' hormones. Biol Reprod 26:55-71

Marzioni D, Fiore G, Giordano A, Nabissi M, Florio P, Verdenelli F, Petraglia F, Castellucci M (2005) Placental expression of substance $\mathrm{P}$ and vasoactive intestinal peptide: evidence for a local effect on hormone release. J Clin Endocrinol Metab 90:2378-2383

Matsubara S, Takahashi T, Kimura AP (2010) Epigenetic patterns at the mouse prolyl oligopeptidase 

gene locus suggest the $\mathrm{CpG}$ island in the gene body to be a novel regulator for gene expression. Gene 465:17-29

3 Matsubara Y, Ono T, Tsubuki S, Irie S, Kawashima S (1998) Transient up-regulation of a prolyl endopeptidase activity in the microsomal fraction of rat liver during postnatal development. Eur J Biochem 252:178-183

Moreno-Baylach MJ, Felipo V, Männistö PT, García-Horsman JA (2008) Expression and traffic of cellular prolyl oligopeptidase are regulated during cerebellar granule cell differentiation, maturation, and aging. Neuroscience 156:580-585

Myöhänen TT, Venäläinen JI, Tupala E, Garcia-Horsman JA, Miettinen R, Männistö PT (2007) Distribution of immunoreactive prolyl oligopeptidase in human and rat brain. Neurochem Res $32: 1365-1374$

Myöhänen TT, Venäläinen JI, Garcia-Horsman JA, Männistö PT (2008a) Spatial association of prolyl oligopeptidase, inositol 1, 4, 5-triphosphate type 1 receptor, substance $\mathrm{P}$ and its neurokinin-1 receptor in the rat brain: an immunohistochemical colocalization study. Neuroscience 153:1177-1189

Myöhänen TT, Venäläinen JI, Garcia-Horsman JA, Piltonen M, Männistö PT (2008b) Cellular and subcellular distribution of rat brain prolyl oligopeptidase and its association with specific neuronal

Myöhänen TT, Venäläinen JI, García-Horsman JA, Piltonen M, Männistö PT (2008c) Distribution of prolyl oligopeptidase in the mouse whole-body sections and peripheral tissues. Histochem Cell Biol 130:993-1003

Myöhänen TT, García-Horsman JA, Tenorio-Laranga J, Männistö PT (2009) Issues about the physiological functions of prolyl oligopeptidase based on its discordant spatial association with substrates and inconsistencies among mRNA, protein levels, and enzymatic activity. J Histochem Cytochem 57:831-848 
modulation of prolyl endopeptidase and dipeptidyl peptidase IV activities in the mouse uterus and ovary. Acta Endocrinol (Copenh) 127:262-266

Ogiwara K, Takano N, Shinohara M, Murakami M, Takahashi T (2005) Gelatinase A and membrane-type matrix metalloproteinases 1 and 2 are responsible for follicle rupture during ovulation in the medaka. Proc Natl Acad Sci USA 102:8442-8447

Ogiwara K, Takahashi T (2007) Specificity of the medaka enteropeptidase serine protease and its usefulness as a biotechnological tool for fusion-protein cleavage. Proc Natl Acad Sci USA 104:7021-7026

Ohtsuki S, Homma K, Kurata S, Komano H, Natori S (1997) Nuclear localization and involvement in DNA synthesis of Sarcophaga prolyl endopeptidase. J Biochem 121:1176-1181

Ohtsuki S, Homma K, Kurata S, Komano H, Natori S (1994) A prolyl endopeptidase of Sarcophaga peregrina (flesh fly): its purification and suggestion for its participation in the differentiation of the imaginal discs. J Biochem 115:449-453

Perroud B, Alvarado RJ, Espinal GM, Morado AR, Phinney BS, Warden CH (2009) In vivo multiplex quantitative analysis of 3 forms of alpha melanocyte stimulating hormone in pituitary of prolyl endopeptidase deficient mice. Mol Brain 2:14

Rennex D, Hemmings BA, Hofsteenge J, Stone SR (1991) cDNA cloning of porcine brain prolyl endopeptidase and identification of the active-site seryl residue. Biochemistry 30:2195-2203

Rossant J, Cross JC (2001) Placental development: lessons from mouse mutants. Nat Rev Genet 2:538-548

Salers P (1994) Evidence for the presence of prolyl oligopeptidase and its endogenous inhibitor in neonatal rat pancreatic beta-cells. Regul Pept 50:235-245

Schulz I, Zeitschel U, Rudolph T, Ruiz-Carrillo D, Rahfeld JU, Gerhartz B, Bigl V, Demuth HU, Rossner S (2005) Subcellular localization suggests novel functions for prolyl endopeptidase in protein secretion. J Neurochem 94:970-979 
Sclafani RA, Holzen TM (2007) Cell cycle regulation of DNA replication. Annu Rev Genet 41:237-280

Shirasawa Y, Osawa T, Hirashima A (1994) Molecular cloning and characterization of prolyl endopeptidase from human T cells. J Biochem 115:724-729

Simmons DG, Cross JC (2005) Determinants of trophoblast lineage and cell subtype specification in the mouse placenta. Dev Biol 284:12-24

Simmons DG, Fortier AL, Cross JC (2007) Diverse subtypes and developmental origins of trophoblast giant cells in the mouse placenta. Dev Biol 304:567-578

Soeda S, Ohyama M, Yamakawa N, Shimeno H, Nagamatsu A (1984) Two molecular species of proline endopeptidase in human plasma: isolation and characterization. Chem Pharm Bull 32:4061-4069

Soeda S, Yamakawa N, Ohyama M, Shimeno H, Nagamatsu A (1985) An inhibitor of proline endopeptidase: purification from rat brain and characterization. Chem Pharm Bull (Tokyo) $33: 24445-24451$

Takahashi T, Athauda SBP, Mori T, Kawashima S, Matsushima M, Ichinose M, Miki K, Takahashi K (1996) Prolyl endopeptidase from the follicular fluid of porcine ovary: Comparison with the liver enzyme. Biomed Res 17:435-442

Tenorio-Laranga J, Venäläinen JI, Männistö PT, Garcia-Horsman JA (2008) Characterization of membrane-bound prolyl endopeptidase from brain. FEBS J 275:4415-4427

Walter R, Shlank H, Glass JD, Schwartz IL, Kerenyi TD (1971) Leucylglycinamide released from oxytocin by human uterine enzyme. Science 173:827-829

Walther T, Jank A, Heringer-Walther S, Horn LC, Stepan H (2008) Angiotensin II type 1 receptor has impact on murine placentation. Placenta 29:905-909

Warden CH, Fisler JS, Espinal G, Graham J, Havel PJ, Perroud B (2009) Maternal influence of prolyl endopeptidase on fat mass of adult progeny. Int J Obes (Lond) 33:1013-1022

Watson ED, Cross JC (2005) Development of structures and transport functions in the mouse placenta. Physiology (Bethesda) 20:180-193 
1 Welches WR, Brosnihan KB, Ferrario CM (1993) A comparison of the properties and enzymatic

2 activities of three angiotensin processing enzymes: angiotensin converting enzyme, prolyl

3 endopeptidase and neutral endopeptidase 24.11. Life Sci 52:1461-1480

4 Wilkinson MG, Millar JB (2000) Control of the eukaryotic cell cycle by MAP kinase signaling pathways.

FASEB J 14:2147-2157

$6 \quad$ Wilk S (1983) Prolyl endopeptidase. Life Sci 33:2149-2157

7 Williams RSB (2004) Prolyl oligopeptidase and bipolar disorder. Clin Neurosci Res 4:233-242

8 Yamanaka C, Lebrethon MC, Vandersmissen E, Gerard A, Purnelle G, Lemaitre M, Wilk S, Bourguignon

9 JP (1999) Early prepubertal ontogeny of pulsatile gonadotropin-releasing hormone (GnRH) secretion:

10 I. Inhibitory autofeedback control through prolyl endopeptidase degradation of GnRH. Endocrinology $140: 4609-4615$

Figure Legends

Fig. 1. Northern blot analysis of POP in various mouse tissues. Total RNA was prepared from the indicated 16 mouse tissues and twenty micrograms of the RNA was electrophoresed and blotted to a nylon membrane. The blot was hybridized with a ${ }^{32} \mathrm{P}$-labeled mouse POP cDNA probe and the signals were detected by autoradiography. The electrophoretic image of $28 \mathrm{~S}$ and $18 \mathrm{~S}$ ribosomal RNAs showed that a similar amount of total RNA was used among these tissues.

Fig. 2. Localization of POP mRNA in the mouse placenta. (A) Placentas were collected from pregnant mice on the indicated embryonic days. Four continuous sections $(10 \mu \mathrm{m})$ were prepared for each placenta and hybridized with digoxigenin-labeled sense or antisense probes for POP or Flt1. The signals were detected by an alkaline phosphatase reaction with the nitroblue tetrazolium/5-bromo-4-chloro-3-indolyl 
phosphate substrate. The Flt1 probe was used as a marker gene for the spongiotrophoblast cell. Probes used are indicated on the left of the images. High POP mRNA expression was observed in the spongiotrophoblast of the junctional zone and the labyrinth layer at E10.5 and E11.5 and only in the spongiotrophoblast thereafter. Note that the POP signal is not very strong in some sections due to the difference of the staining time. The scale bar represents $1 \mathrm{~mm}$. Jz, junctional zone; La, labyrinth; Md, maternal decidua. (B) Enlarged images of the boxed regions of E11.5 and E15.5 placentas in A are shown at right. Each image represents the labyrinth and the junctional zone, respectively. To show the morphology of each placental region, images with hematoxylin and eosin staining (HE staining) are also provided at left. While most cells were stained in the labyrinth at E11.5, only S-TGC was positive in the E15.5 placenta. P-TGC, spongiotrophoblast cells, and decidual cells were positive for the POP mRNA signal at both stages. The scale bar represnts $50 \mu \mathrm{m}$. Md, maternal decidua; P-TGC, parietal-trophoblast giant cell; SpT, spongiotrophoblast; S-TGC, sinusoidal-trophoblast giant cell.

Fig. 3. POP protein expression in the mouse placenta. (A) Placental POP activity during gestation. Soluble tissue extracts from placentas (E10.5-E18.5) were prepared and specific POP activity toward Sac-Gly-Pro-Leu-Gly-Pro-MCA was measured. The enzymatic reaction was performed at $37^{\circ} \mathrm{C}$ for 20 min. The activity was expressed as the amount of AMC released per minute per mg protein under the condition. The data are shown as the average \pm SD from six independent experiments with three tissues and analyzed by one-way ANOVA followed by Tukey’s post hoc test. $n=6 ; F=14.59 ;{ }^{* *}, P<0.01$ compared to E10.5. (B) Confirmation of the specificity of the POP antibody generated in this study. Western blot analysis was conducted with soluble extracts of the mouse placenta (E18.5) and brain as well as the purified recombinant POP (rPOP) containing 52 extra amino acids (+ 52 a.a.). The samples were separated by SDS-PAGE with an $8 \%$ gel and blotted to a PVDF membrane. After the blocking with Block Ace and normal rabbit serum sequentially, the membrane was incubated with the purified anti-POP antibody (3 lanes at left). The membranes were then incubated with horseradish peroxidase conjugated 
secondary antibody and the signals were developed using an Immobilon Western Chemiluminescent HRP

Substrate. The experiment was also performed by using the POP antibody preincubated with the rPOP and this resulted in the complete elimination of the POP band (Pre-absorbed, 3 lanes at right). $\beta$-actin was used as an internal control. Positions of molecular marker bands are indicated at left. (C, D) Western blot analysis of POP in various stages of mouse placentas. Western blot was conducted as in B using soluble placental extracts (E10.5-E18.5). We repeated the experiment three times, measured the intensity of each band using the Image J program, and normalized the POP signal to $\beta$-actin. The resulting graph is shown in $\mathrm{C}$ and a representative Western result is indicated in $\mathrm{D}$. The data are shown as the average $\pm \mathrm{SD}$ and analyzed by one-way ANOVA followed by Tukey's post hoc test. $n=3 ; F=0.36$.

Fig. 4. Immunohistochemistry of POP in the E11.5 placenta. The placenta was fixed in Bouin's solution, embedded in paraffin, and sectioned at $6 \mu \mathrm{m}$. The slides were dewaxed, boiled in $10 \mathrm{mM}$ citric acid buffer, and treated with $2.25 \% \mathrm{H}_{2} \mathrm{O}_{2}$. After the blocking with Block Ace followed by normal rabbit serum, the slides were incubated with the purified anti-POP polyclonal antibody and then with HRP conjugated secondary antibody. The signals were developed using AEC Peroxidase Substrate kit. POP immunoreactivity is indicated by red color. Images before (A, C, F) and after counter staining with Carazzi's hematoxylin (D, F) are shown. Three layers are outlined by dashed lines in A. Panels A and B are pictures with low magnification and B represents a control section treated with the primary antibody, which was preincubated with the recombinant POP protein, showing no positive signals. Magnified images of the junctional zone and maternal decidua $(\mathrm{C}, \mathrm{D})$ and the labyrinth layer $(\mathrm{E}, \mathrm{F})$ are indicated. The scale bar represents $200 \mu \mathrm{m}$ in A and B and $50 \mu \mathrm{m}$ in the other pictures. Al, allantois; Jz, junctional zone; La, labyrinth; Md, maternal decidua; P-TGC, parietal TGC; SpT, spongiotrophoblast cell; S-TGC, sinusoidal TGC.

Fig. 5. Immunohistochemistry of POP in the E16.5 (A-L) and E18.5 placentas (M-X). 
Immunohistochemistry was performed as in Fig. 4. POP immunoreactivity is indicated by red color. Images before (A, C, E, G, I, K, M, O, Q, S, U, W) and after counter staining with Carazzi's hematoxylin (D, F, H, J, L, P, R, T, V, X) are shown. Three layers are outlined by dashed lines in A, B, M, and N and these panels are pictures with low magnification. $\mathrm{B}$ and $\mathrm{N}$ indicate control sections treated with the primary antibody, which was preincubated with the recombinant POP protein, showing no positive signals. Magnified images of the junctional zone (C, D, O-R) and the labyrinth layer (E-H, S-V) are indicated. In the E16.5 placenta, the glycogen trophoblast cell and the allantois are further enlarged in I-L. In the E18.5 placenta, we could also identify SpA-TGC (W, X). The scale bar represents $200 \mu \mathrm{m}$ in A, E, I, and M and $50 \mu \mathrm{m}$ in the other pictures. Al, allantois; C, canal lumen; C-TGC, canal-associated TGC; GlyT, glycogen trophoblast cell; Jz, junctional zone; La, labyrinth; Md, maternal decidua; P-TGC, parietal TGC; SpA, spiral artery lumen; SpA-TGC; spiral artery-associated TGC; S-TGC, sinusoidal TGC; SpT, spongiotrophoblast cell.

Fig. 6. Subcellular distribution of POP in the mouse placenta. (A) The cytoplasmic and membrane subfraction $(\mathrm{C}+\mathrm{M})$ were separated from the nucleus $(\mathrm{N})$ using E10.5 and E15.5 placentas. Specific POP activity of each fraction was measured as in Fig. 3A but the enzymatic reaction was performed for $60 \mathrm{~min}$. The data are shown as the average \pm SD from six independent experiments with three tissues and analyzed by Student's $t$ test. $n=6$; **, $P<0.01$ compared with $\mathrm{N}$ fraction of each stage of placenta. (B) Western blot analysis was performed as in Fig. 3B using the $\mathrm{C}+\mathrm{M}$ and $\mathrm{N}$ fractions prepared in $\mathrm{A}$. (C) The extracts from E11.5 and E16.5 placentas were fractionated into cytoplasmic (C), membrane (M), and nuclear $(\mathrm{N})$ subfractions. The enzymatic activity assay was conducted as in A. The enzyme activity assay was conducted independently six times with three tissues. The data were analyzed by one-way ANOVA followed by Tukey's post hoc test. $n=6 ; F=113.12$ and 454.72 in the E11.5 and E16.5 placenta, respectively; ${ }^{* *}, P<0.01$ compared with $\mathrm{N}$ fraction of each placenta. (D) Western blot analysis was repeated three times and a representative result is shown. The intensity of each band was measured by 
1 using Image $\mathrm{J}$ program and the POP signal was normalized to $\beta$-actin and indicated as a graph. The

2 antibodies against histone $\mathrm{H} 3$ and connexin-43 were used as markers of the nucleus and plasma

3 membrane, respectively. A non-specific band was somehow detected just below the connexin-43 band in

4 the E11.5 placenta. The data are shown as the average \pm SD from three independent experiments with two

5 tissues and analyzed by one-way ANOVA followed by Tukey's post hoc test. $n=3 ; F=9.07$ and 14.48 in

6 the E11.5 and E16.5 placenta, respectively; *, $P<0.05$ and **, $P<0.01$ compared with $\mathrm{N}$ fraction of each

7 placenta.

8 
Table 1

POP expression summary of the immunohistochemistry.

\begin{tabular}{lccc}
\hline & E11.5 & E16.5 & E18.5 \\
\hline maternal decidua & & & \\
decidual cell & ++ & ++ & ++ \\
SpA-TGC & $\mathrm{ND}$ & $\mathrm{ND}$ & +++ \\
P-TGC & +++ & +++ & +++ \\
junctional zone & & & \\
$\quad$ spongiotrophoblast cell & +++ & +++ & +++ \\
glycogen trophoblast cell & $*$ & + & + \\
labyrinth layer & & & \\
S-TGC & +++ & +++ & +++ \\
C-TGC & $\mathrm{ND}$ & +++ & +++ \\
allantois & - & - & - \\
other cells & +++ & $+/ * *$ & $+/$-** \\
\hline
\end{tabular}

*, Glycogen trophoblast cells are not present in E11.5 placenta.

**, Most cells are negative, but some cells may have weak POP-immunoreactivity.

SpA-TGC, spiral artery-associated TGC; P-TGC, parietal TGC; S-TGC, sinusoidal

TGC; C-TGC, canal-associated TGC; ND, not determined 


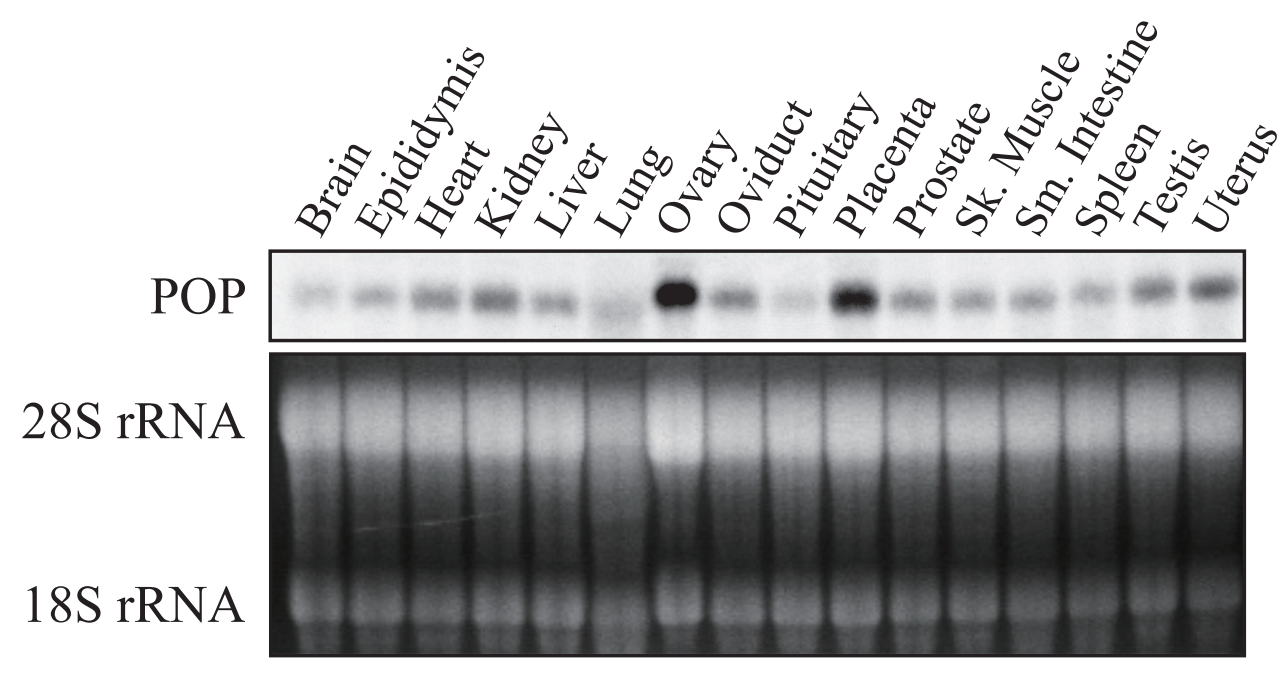

Fig.1 
A

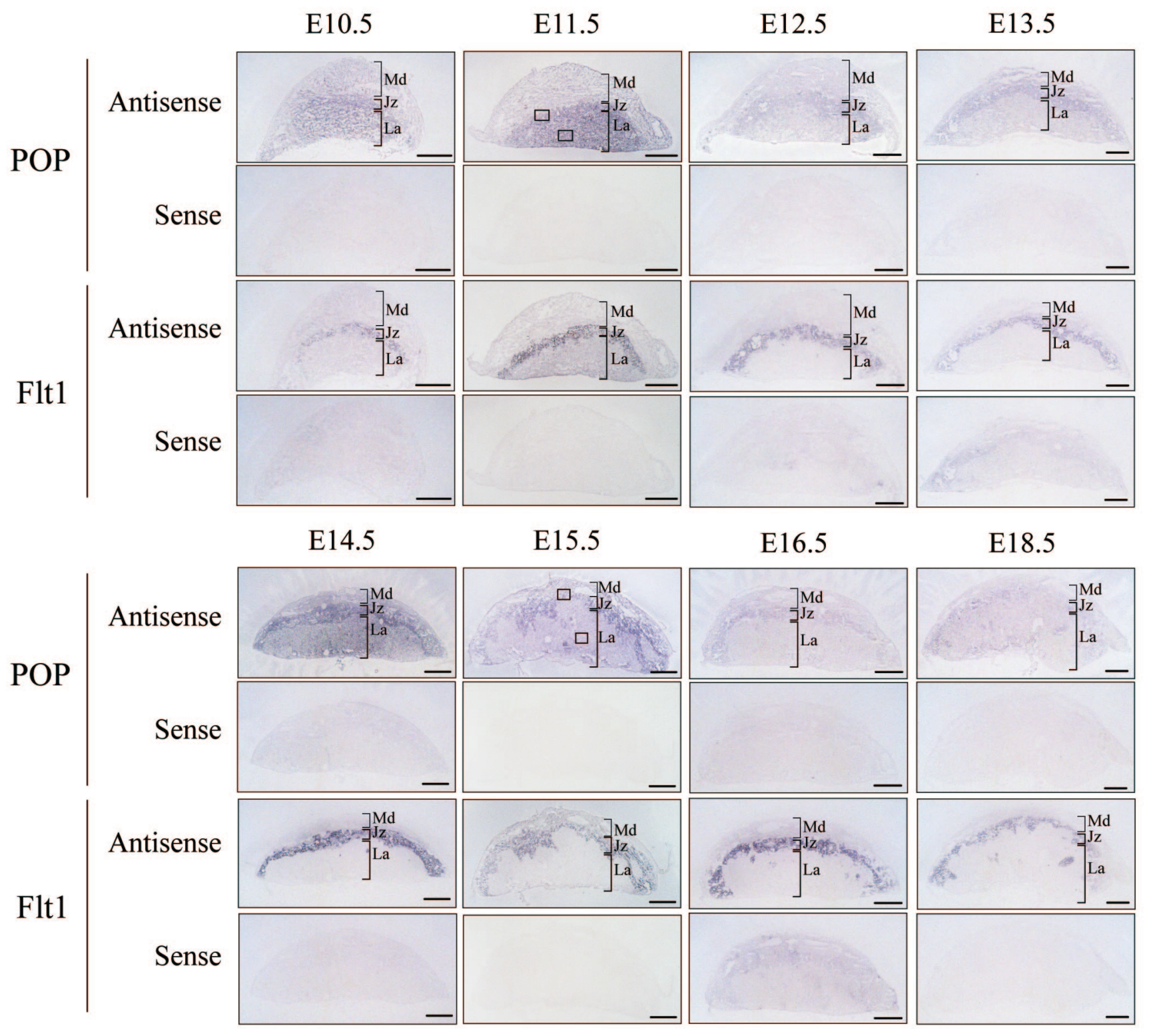

B

E11.5

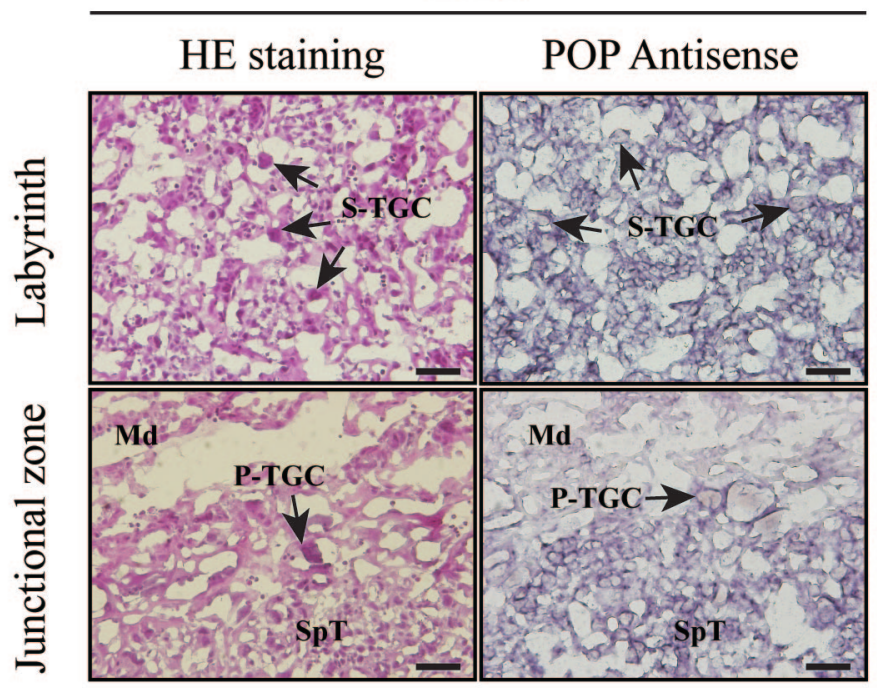

E15.5

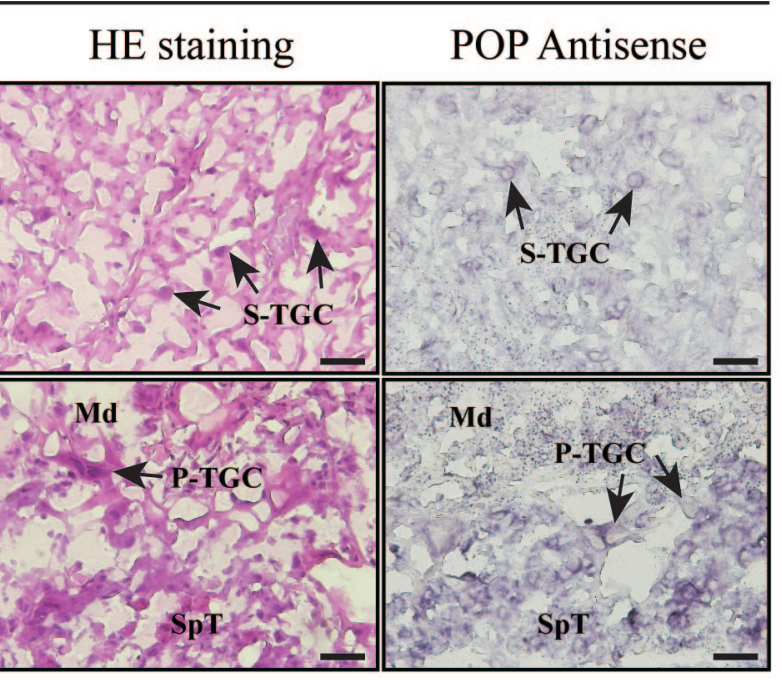


A

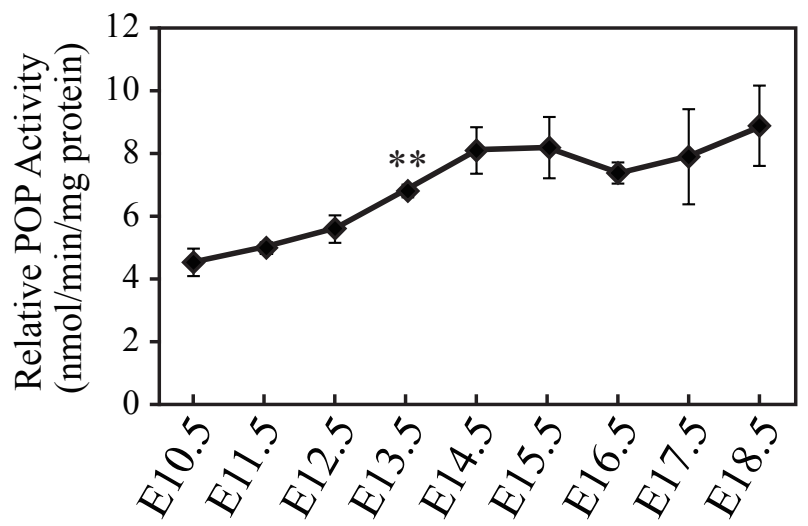

B (kDa)
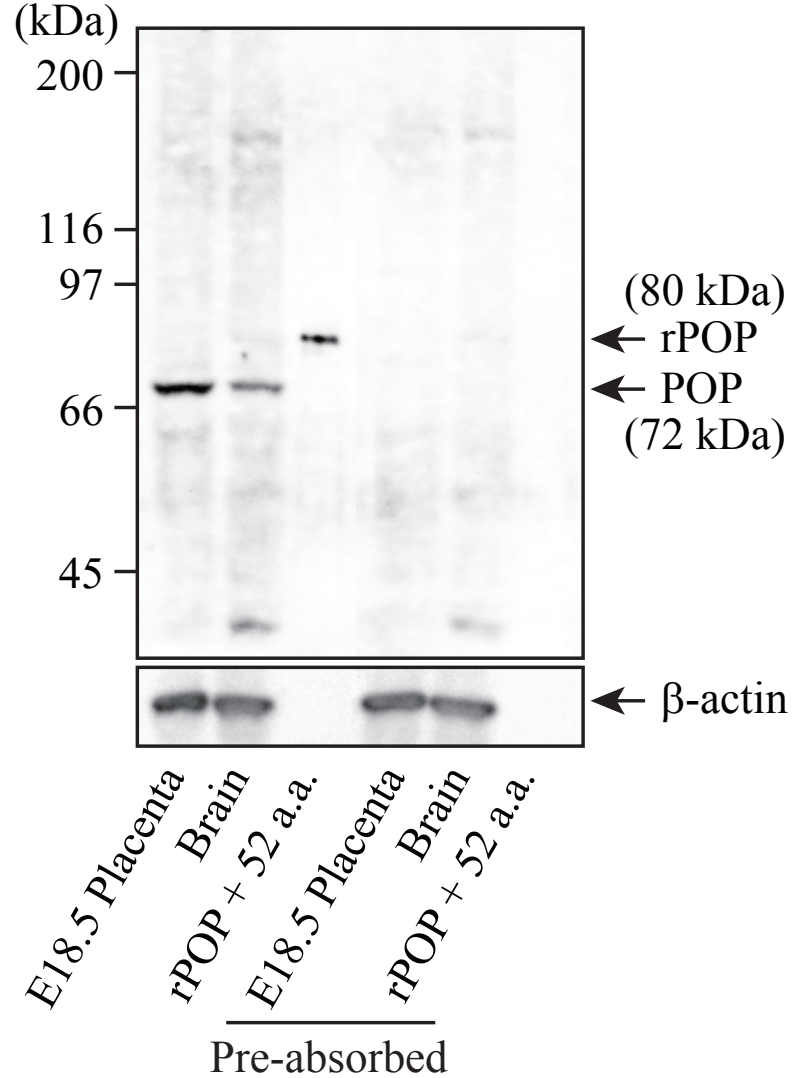

C

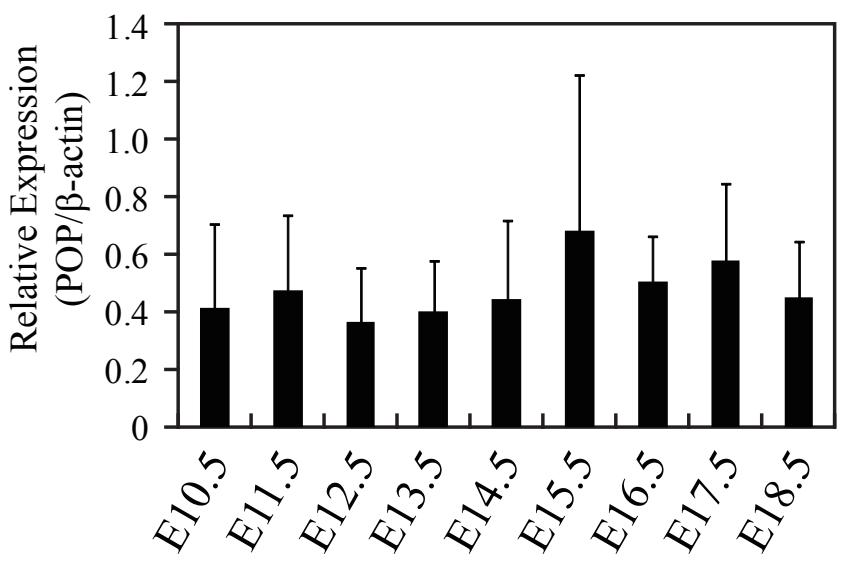

D

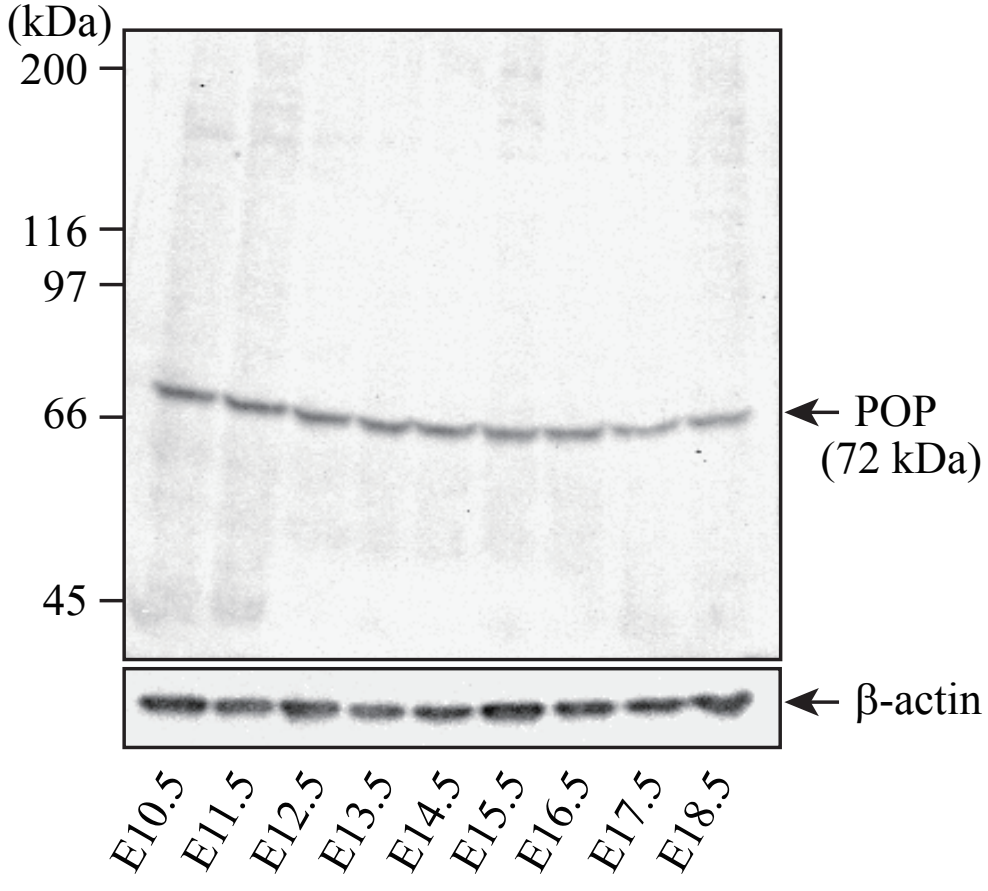

Fig.3 


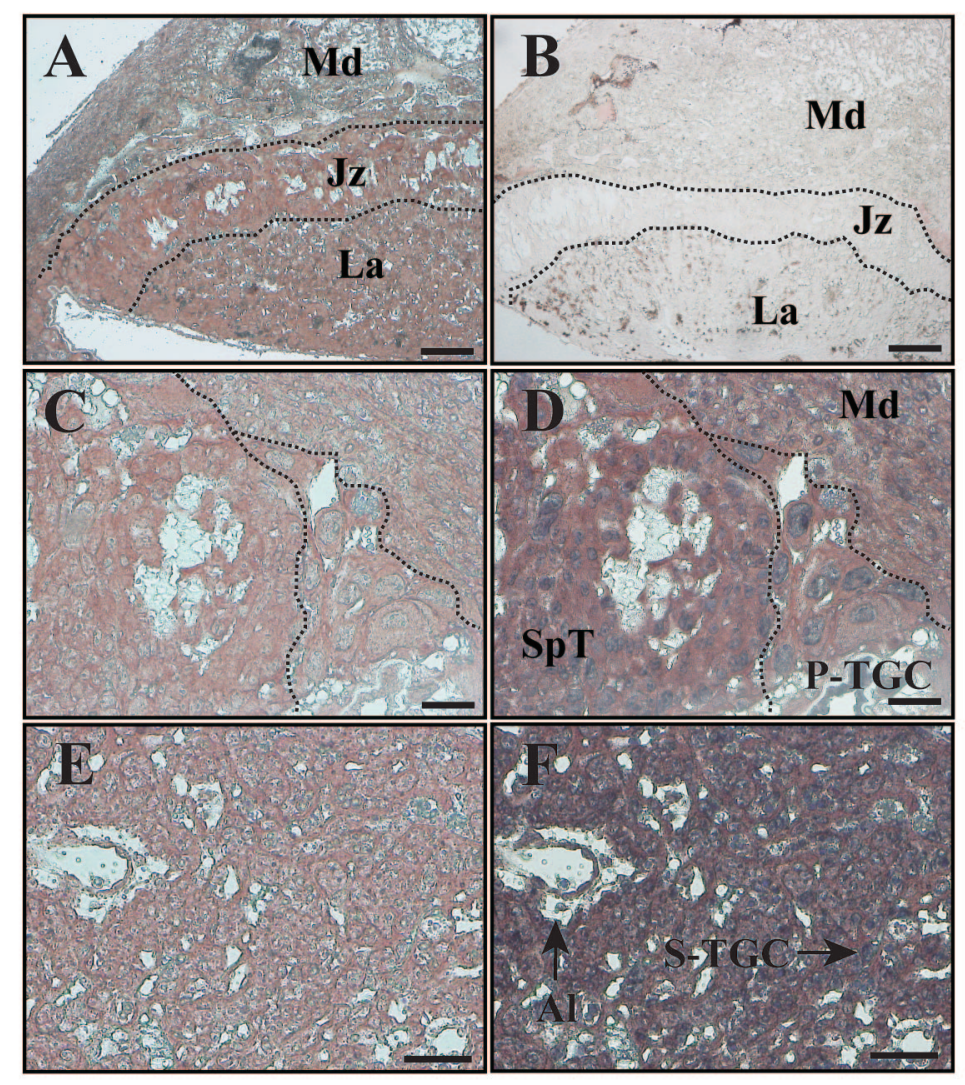

Fig.4 

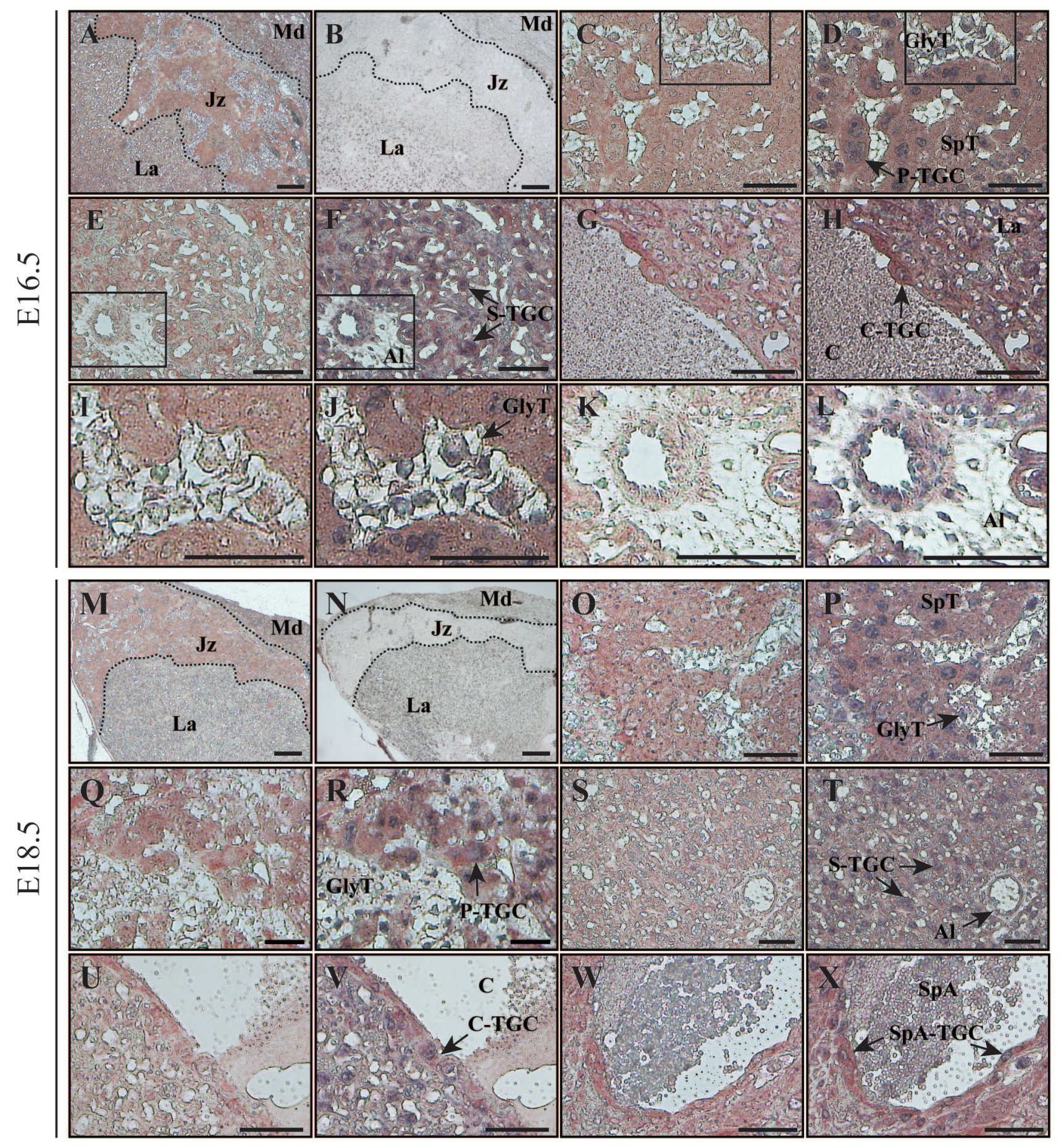

Fig.5 
A

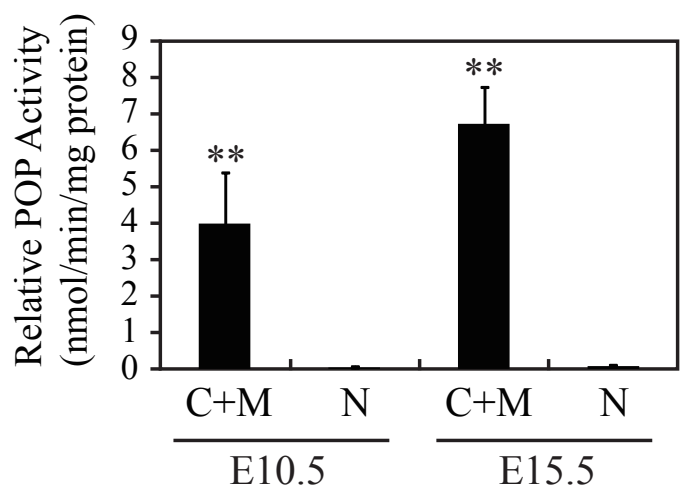

C

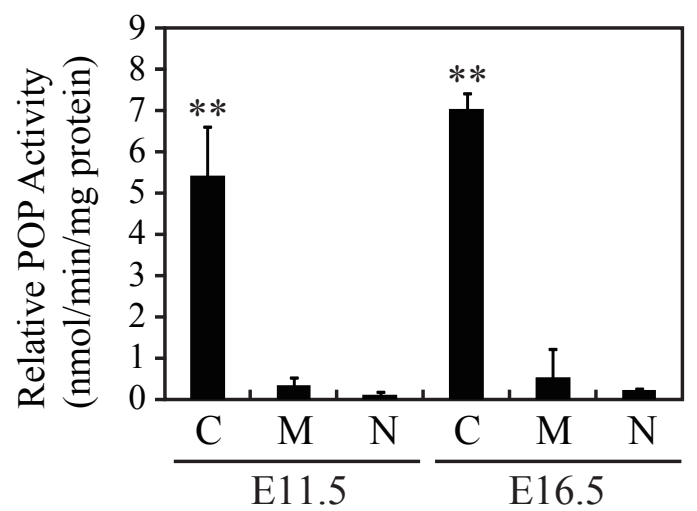

B

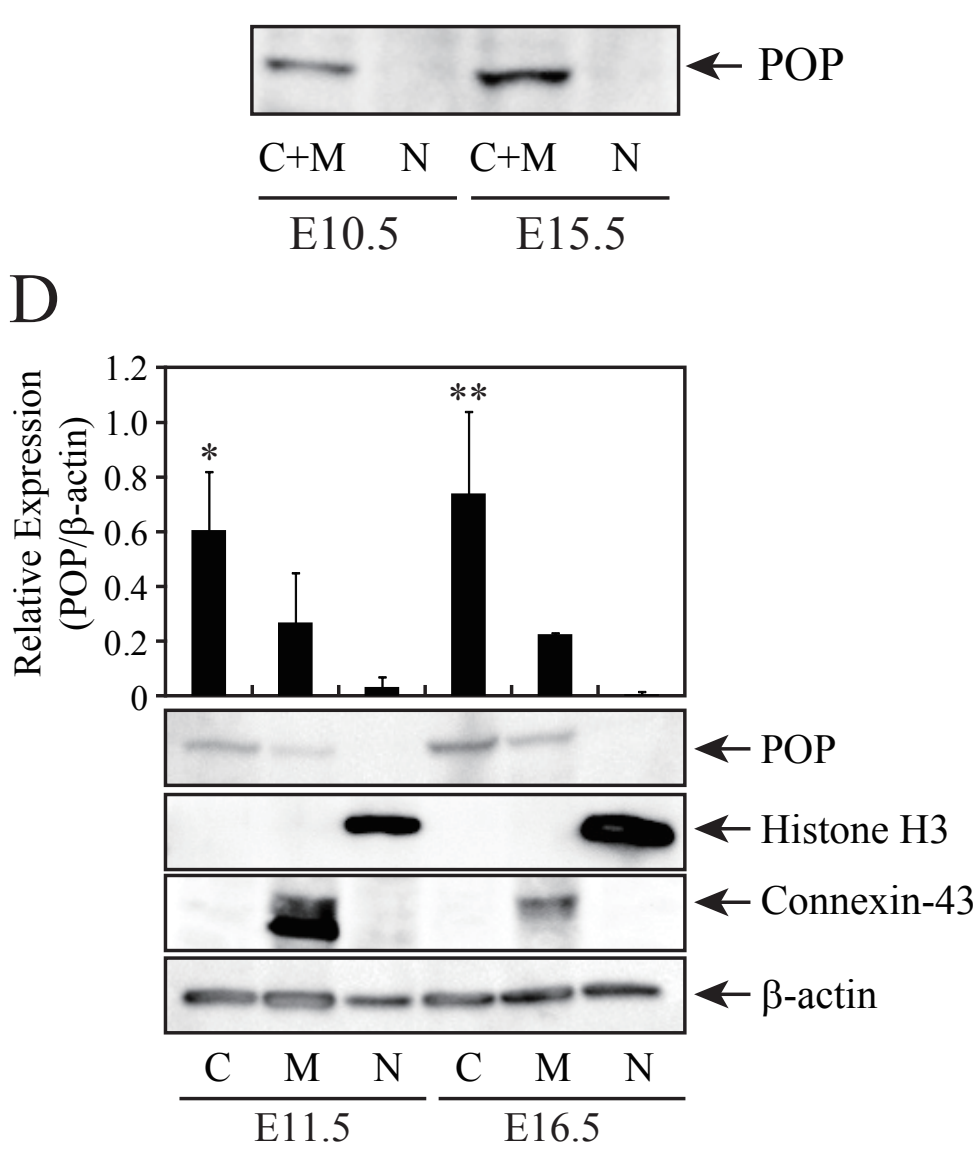

Fig.6 